\title{
THE EFFECT OF FIRE ON THE STRENGTH OF CONCRETE MATERIAL
}

\author{
HM Iqbal Mahmud*, Md Kawser Babu Raju and Md Lokman Hosen \\ Department of Civil Engineering, Khulna University of Engineering \& Technology, Bangladesh \\ Received: 07 May 2019 \\ Accepted: 14 March 2021
}

\begin{abstract}
Structural members exposed to fire may damage considerably, lose their durability, and even collapse due to the failure of the members. This work presents the results of an experimental investigation of the effect of fire on the strength of concrete. Cylindrical and beam specimens were prepared and burnt in the fire for one hour. In both cases, two systems were followed for cooling the samples, (i) natural cooling in the air (ii) forced cooling in the water. Afterwards, the compressive and flexural strength of the specimens were determined. The result shows that the strength of concrete was considerably reduced due to burning in fire. The compressive strength of cylindrical specimens was decreased by $44 \%$ and 60\%, respectively, for the natural and forced cooling of the specimens. In the case of beam samples, the flexural strength was decreased $60 \%$ and $69 \%$, respectively, for the natural and forced cooled specimens. This research also reveals that the specimen cooled in air showed better performance compared to that cooled in water.
\end{abstract}

Keywords: Concrete; Compressive Strength; Fire; Forced Cooling; Natural Cooling.

\section{INTRODUCTION}

The recent fire incidents are alarming the risk of fire and safety issues in Bangladesh. It is one of the major causes of huge damage and losses of properties in Bangladesh (Department of Disaster Management, 2013). For building construction, concrete is one of the main load-carrying parts of a reinforced concrete structure. However, the strength of concrete is significantly affected due to the high temperature of the fire. This may cause undesirable structural failures (Ali et al., 2004; Georgali and Tsakiridis, 2005; Xiao and Konig, 2005).

During a fire, the temperature may reach up to $1100^{\circ} \mathrm{C}$ in buildings and even up to $1350^{\circ} \mathrm{C}$ in tunnels (Hager, 2013). The exposure of concrete structural elements to high temperature leads to significant losses in its structural capacity due to the reduction in its strength of the concrete and, most importantly, due to loss of bond between the aggregate and binding materials (Khalaf, 2017; Haddad et al., 2008). So, information on the degree of strength degradation is required for the structural design of fire safety and structural repair after a fire incident. This evaluation of the degree of deterioration of the concrete properties will enable engineers to decide whether a structure after exposure to high temperatures can be repaired rather than required to be demolished. Another essential concern is the cooling of the concrete member during or after a fire incident. The method of cooling the hot concrete member may affect its strength. If a concrete member is cooled slowly or naturally in the air, its property may differ from that one cooled immediately in water. Thus, it is necessary to investigate the mechanical properties of concrete to predict its lifetime and durability after a fire hazard. Hence, this study aims to investigate the effect of fire on the mechanical properties of concrete. The specific objectives of this study can be listed as; (1) to investigate the effect of burning of concrete specimens in fire by testing the compressive and flexural strength of the burnt specimens; (2) to investigate the effect of the cooling process on the hot specimens after burning in the fire; and (3) to investigate the physical effects of fire (spalling, cracks etc.) on the specimens.

\section{METHODOLOGY AND EXPERIMENTAL PROGRAM}

\subsection{Materials}

For the preparation of concrete, ordinary Portland cement, Sylhet sand (fine aggregate) and locally available stone chips were used. The nominal size of the coarse aggregate was $19 \mathrm{~mm}$. The properties of fine and coarse aggregates are presented in Table 1. 
The casting of specimens was completed with a mix ratio of $1: 1.5: 3$, giving water to cement ratio of 0.635 with a target strength of $3500 \mathrm{psi}(24 \mathrm{MPa})$. Mix design of concrete was performed according to ACI 211.1, and the concrete mixing was performed according to ASTM C192 using a standard concrete mixture. At each time of casting of the concrete specimen, the slump was determined and it was within 100-120 mm. Nine cylindrical specimens of diameter $100 \mathrm{~mm}$ and height $200 \mathrm{~mm}$ were prepared to determine the compressive strength of concrete after burning in fire. Among these nine specimens, three specimens were used as the reference specimens (virgin specimen), which were tested without burning in the fire, and the other six specimens were burnt in the fire. Out of six specimens, which were burnt in the fire, three were cooled naturally in air and three were cooled forcedly in water. Similar to the cylindrical specimens, nine numbers of beam specimens of $100 \times$ $100 \mathrm{~mm}$ cross-section and $450 \mathrm{~mm}$ long were cast to examine the flexural strength of concrete. Among the nine specimens, three were kept for testing without burning (virgin specimens), and six were kept for burning in fire. Among the six specimens, which were kept for burning, three were cooled naturally in air and three were cooled forcedly in water.

Table 1: Material properties.

\begin{tabular}{lll}
\hline Materials & Properties & Value \\
\hline Coarse Aggregate & Specific Gravity & 2.45 \\
& Absorption, \% & 3.34 \\
& Unit Weight, $\mathrm{Kg} / \mathrm{m}^{3}$ & 1510 \\
Fine Aggregate & Specific Gravity & 2.54 \\
& Absorption, \% & 2.74 \\
& Fineness Modulus & 2.65 \\
& Unit Weight, $\mathrm{Kg} / \mathrm{m}^{3}$ & 1615 \\
\hline
\end{tabular}

\subsection{Burning of the specimens}

A fire chamber was prepared to burn the samples in the fire. The chamber was in a dimension of $500 \times 500 \times 600$ $\mathrm{mm}$. The specimens were kept inside the chamber, and the fire was produced by dry wood. The wood was placed by layer so that sufficient oxygen could flow during the fire. Then specimens were placed on a platform prepared by steel, placing above the layer of firewood. The temperature during the burning of the specimens was about $800-1000^{\circ} \mathrm{C}$. For both cases, the specimens were burnt in the fire for a duration of one hour, without any imposed load on the specimens during the burning.

\subsection{Cooling of the specimens}

After burning the specimens, they were cooled in two processes. Among the six cylindrical specimens, three were immersed in water immediately after burning in fire and three were kept in the open air for natural cooling. The first process of cooling represents the immediate cooling of the specimens, which resemble the application of water in a building for the suppression of fire by the fire-fighters during a fire incident in that building, and the second process resembles the cooling of the structural members of a building after a fire incident without any application of water or any other fire suppression agent. The same cooling processes were also applied to the beam specimens.

\subsection{Testing of the specimens}

After performing the burning and cooling processes, the specimens were tested in the laboratory, according to ASTM C39. The cylindrical specimens were crushed by a compressive testing machine, and the ultimate capacity of the samples was recorded. The flexural strength of concrete beams was determined by testing the specimens following the three-point loading test method according to ASTM C78. The results are summarised in the following sections.

\section{RESULTS AND DISCUSSIONS}

\subsection{Compressive strength of the cylindrical specimens}

In this study, nine cylindrical specimens were tested, and the compressive strength of concrete was determined. Among the nine specimens, as described in the previous section, three were tested without burning (virgin sample), six samples were burnt in the fire. The specimens were burnt for 60 minutes. After burning the specimens in the fire, three were kept in the open air for natural cooling, and three were immersed in a water 
chamber for immediate cooling. Afterwards, the specimens were tested in a compression testing machine, and the results are summarised in Table 2.

The strength of samples, burnt and cooled in different ways, were compared to that of the virgin sample and presented in Figure 1. In the analysis, it has been observed that the strength of concrete was decreased considerably due to the burning in fire. The average compressive strength of the unburnt specimens was 23.33 $\mathrm{MPa}$, whereas this strength for burnt samples was only 12.95 and $9.25 \mathrm{MPa}$, for naturally and forcedly cooled specimens, respectively. The average percent loss of strength due to burning in the fire was $44 \%$ and $60 \%$ for naturally and forcedly cooled specimens, respectively.

Table 2: Test results of the compressive strength of the cylindrical specimens.

\begin{tabular}{lccccc}
\hline \multicolumn{2}{c}{ Test condition } & $\begin{array}{c}\text { Sample } \\
\text { No }\end{array}$ & $\begin{array}{c}\text { Compressive } \\
\text { Strength (MPa) }\end{array}$ & $\begin{array}{c}\text { Average } \\
\text { Compressive } \\
\text { Strength (MPa) }\end{array}$ & $\begin{array}{c}\text { Average \% Loss of } \\
\text { Strength w.r.t the } \\
\text { Virgin Sample }\end{array}$ \\
\hline $\begin{array}{l}\text { Samples without } \\
\text { burning in fire }\end{array}$ & Virgin & 1 & 23.17 & & - \\
& sample & 2 & 23.44 & 23.33 & \\
& Natural & 1 & 22.95 & & $44 \%$ \\
Samples burnt in & cooling & 2 & 14.63 & & \\
the fire & & 3 & 12.40 & & \\
& Forced & 2 & 10.24 & & \\
& cooling & 3 & 9.13 & 9.25 & \\
\hline
\end{tabular}
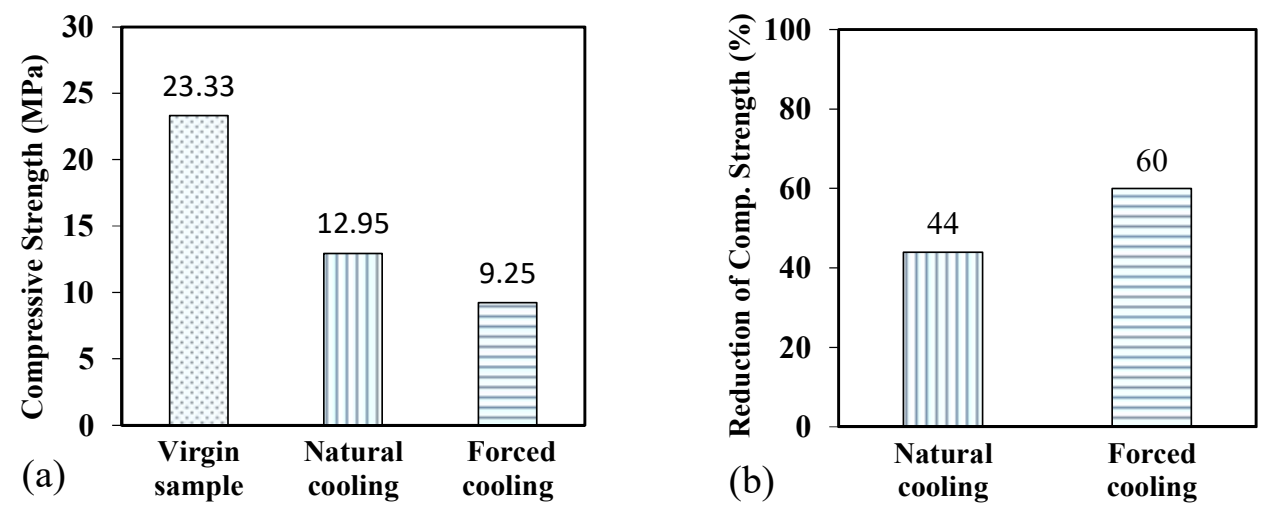

Figure 1: Comparison of test results of compressive strength of cylindrical specimens at different conditions;

(a) compressive strength, (b) reduction of compressive strength.

The reasons for the reduction of the strength of concrete are that it contains chemically bound and free water inside the volume. Due to high temperature, dehydration takes place in the concrete, and as a result, the chemically bound water from the calcium silicate hydrates $(\mathrm{CSH})$ releases into the concrete (Khoury et al., 2002). However, some of this unbound water, in addition to the free water, is trapped in the impervious layer of the concrete and create a huge amount of vapour pressure inside the concrete (Kalifa et al., 2000; Hertz, 2005). Another phenomenon is that when concrete is burnt in the fire, due to very low thermal conductivity, the outer surface of the concrete member is at a higher temperature compared to the deeper layers; as a result, significant temperature gradients are created along with the depth of the concrete member and generates thermal strain inside the concrete (fib, 2007; Hager, 2013). Furthermore, as concrete is a composite material, the thermal property of the individual ingredient is different. Due to the heating of concrete, the aggregate volume grows, but the cement pastes volume contracts caused by the chemical changes in the paste; for example, dehydration, breakdown of the CSH gel, etc. (Hager, 2013). As a result, the aggregate and cement paste bond weakens. Therefore, all of these phenomena cause severe microstructural changes in the concrete, and the effects are usually visible in the form of surface cracking (Arioz, 2007; Ali et al., 2004; Cioni et al., 2001; Ichikawa and England, 2004; Hertz and Sorensen, 2005). Eventually, the strength of the concrete is significantly reduced. 
This study also reveals that the strength of the specimens cooled in water was further reduced compared to that cooled in air. The possible reason is that due to sudden cooling in water, the outer surface of the sample was cooled immediately, but the inner part of the sample was in high temperature. As a result, thermal stress was developed in the sample, which may lead to crack in the specimens. However, this requires further detail investigation to examine the specific reason for the degradation of strength due to the sudden cooling of hot concrete specimens in water.

\subsection{Flexural strength of the beam specimens}

Nine beam specimens were tested, and the flexural strength of concrete was determined. The flexural strength from the tests of the specimens at ambient temperature and after exposure to fire at high temperature are presented in Table 3.

Table 3: Test results of the flexural strength of the beam specimens.

\begin{tabular}{|c|c|c|c|c|c|}
\hline \multicolumn{2}{|c|}{ Test Condition } & \multirow{2}{*}{$\begin{array}{c}\text { Sample } \\
\text { No } \\
1\end{array}$} & \multirow{2}{*}{$\begin{array}{c}\text { Flexural } \\
\text { Strength } \\
(\mathrm{Mpa})\end{array}$} & \multirow{2}{*}{$\begin{array}{c}\text { Average } \\
\text { Flexural } \\
\text { Strength (Mpa) }\end{array}$} & \multirow{2}{*}{$\begin{array}{l}\text { Average \% Loss } \\
\text { of Strength w.r.t } \\
\text { the Virgin Sample }\end{array}$} \\
\hline \multirow{3}{*}{$\begin{array}{l}\text { Specimens without } \\
\text { burning in fire }\end{array}$} & \multirow{3}{*}{$\begin{array}{l}\text { Virgin } \\
\text { sample }\end{array}$} & & & & \\
\hline & & 2 & 6.45 & \multirow[t]{2}{*}{6.40} & \multirow[t]{2}{*}{-} \\
\hline & & 3 & 5.98 & & \\
\hline \multirow{6}{*}{$\begin{array}{l}\text { Specimens burnt } \\
\text { in fire }\end{array}$} & \multirow{3}{*}{$\begin{array}{c}\text { Air } \\
\text { cooling }\end{array}$} & 1 & 2.90 & \multirow{3}{*}{2.55} & \multirow{3}{*}{$60 \%$} \\
\hline & & 2 & 2.48 & & \\
\hline & & 3 & 2.28 & & \\
\hline & \multirow{3}{*}{$\begin{array}{l}\text { Water } \\
\text { cooling }\end{array}$} & 1 & 2.27 & \multirow{3}{*}{2.00} & \multirow{3}{*}{$69 \%$} \\
\hline & & 2 & 2.02 & & \\
\hline & & 3 & 1.85 & & \\
\hline
\end{tabular}
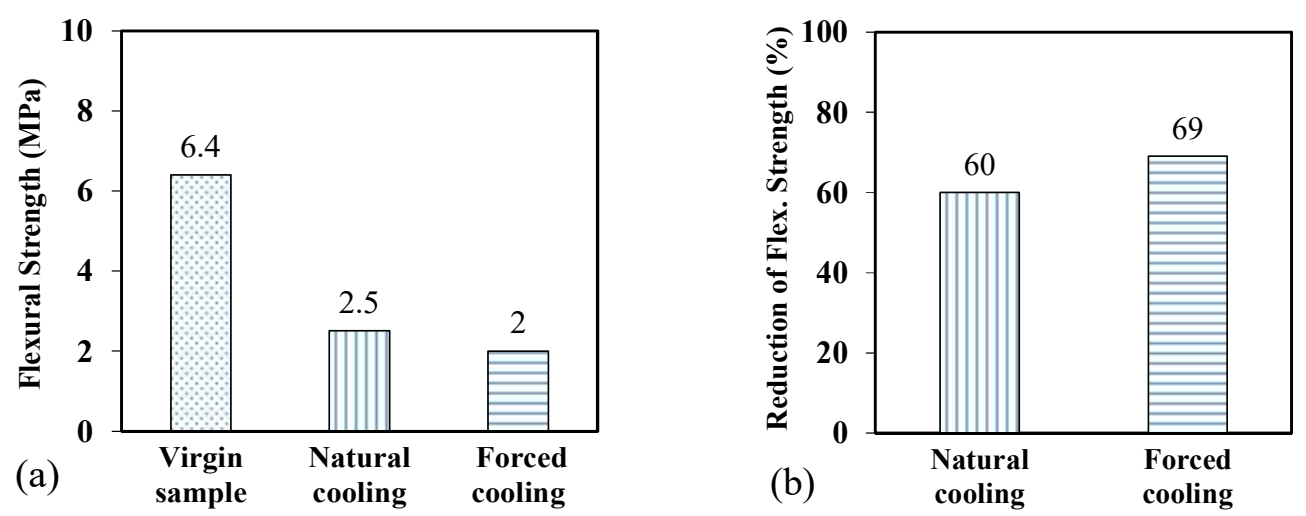

Figure 2: Comparison of test results of flexural strength of beam specimens at different conditions; (a) flexural strength, (b) reduction of flexural strength.

In the analysis, it has been observed that the strength of the specimens was significantly reduced due to burning in fire. The effect of the cooling process on the strength of the beam was also examined in the experiment, as it was done in the cylindrical specimens. In the analysis, it has been found that the average flexural strength was 6.4 $\mathrm{MPa}$ at ambient temperature, whereas this value was $2.55 \mathrm{MPa}$ and $2.0 \mathrm{MPa}$ for naturally and forcedly cooled specimens, respectively. Due to burning in the fire, the flexural strength was reduced by about $60 \%$ and $69 \%$ for natural cooling and forced cooling of the specimens, respectively. The result also reveals that due to the sudden cooling of the sample in water, the strength of the concrete reduced more than the sample cooled slowly in natural air. The comparison of results is also presented graphically in Figure 2.

It is important to note that the reduction of flexural strength of the reinforced beam is higher than that of the compressive strength of the concrete cylinder due to burning in fire. The reduction of strength was due to the reduction of the bond between steel (Lublóy and György, 2014) and concrete in addition to the reduction of the strength of concrete, as discussed in the previous section. 


\subsection{Spalling and cracks in the specimens}

Spalling and cracking are a common phenomenon in concrete during burning in. As concrete is not a product of a single material, cracks develop due to the thermal incompatibility among the individual ingredient of concrete (i.e. coarse aggregate, fine aggregate and cement) when it is exposed to fire or high temperature. Furthermore, due to high temperature, a huge amount of vapour pressure is developed in the concrete's moisture clog region, which leads to the occurrence of spalling of concrete (Hager, 2013; Kalifa et al., 2000). Spalling results in loss of volume in concrete member and reduction in the load-bearing capacity of the member. These phenomena were also observed in the experiment during the burning of the samples and shown in Figures 3.
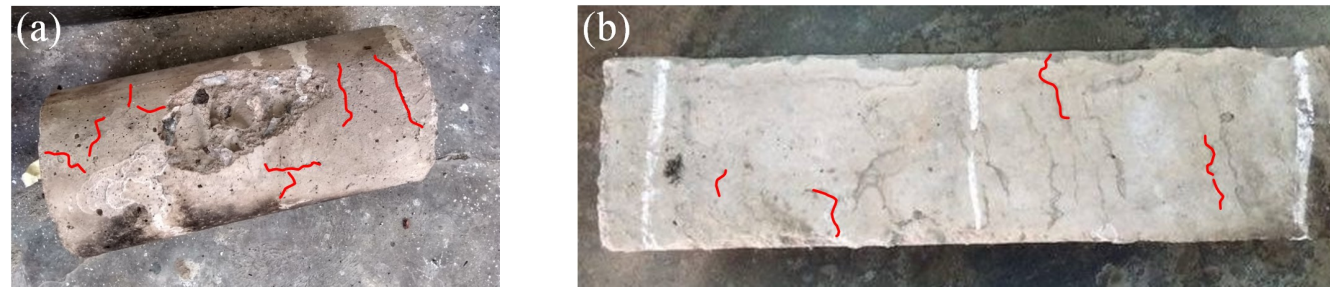

Figure 3: Spalling and cracks in specimens; (a) cylindrical specimen, (b) beam specimen.

\section{CONCLUSIONS}

This study was aimed to evaluate the behaviour of concrete beam exposed to fire. The effect of the cooling process on the burnt specimens of concrete was also investigated. Nine cylindrical and nine beam specimens of concrete were prepared for the test. Among the nine cylindrical specimens, three were used as virgin specimens, which were tested without burning in the fire, and six specimens were burnt in the fire. To examine the effect of the cooling process, three were cooled naturally in the air, and three were cooled immediately in water. The natural cooling in the air represents the slow process of cooling, and forced cooling in water represents immediate cooling which resembles the suppression of fire by the fire-fighters during a fire incident in a building. The same procedure was also followed for the nine beam specimens. Subsequently, all of the specimens were tested in the compression testing machine.

The result shows that both compressive and flexural strength of concrete was reduced significantly due to burning in fire. The strength of concrete was also affected by the cooling process of the sample. It has been found that the strength of concrete was reduced more due to immersion in water compared to the samples cooled naturally in the air. The compressive strength of concrete was reduced by about $60 \%$ and $44 \%$ for forced cooling and natural cooling, respectively, compared to that of the unburnt specimen. In the case of the beam specimens, the flexural strength of concrete was reduced, due to burning in the fire, about $69 \%$ and $60 \%$, for natural cooling and forced cooling of the samples, respectively. The spalling of concrete due to burning in the fire was also observed in the experiments. Further study is recommended to examine the effect of fire on the reinforced concrete beams.

\section{REFERENCES}

ACI Committee 211, 2002. Standard Practice for selecting proportions for Normal, Heavyweight, and Mass Concrete (ACI 211.1-91), American Concrete Institute, Farmington Hills.

Ali, F., Nadjai, A., Silcock, G. and Abu-Tair, A., 2004. Outcomes of a major research on fire resistance of concrete columns, Fire Safety Journal, 39, 433-445.

Arioz, O., 2007. Effects of elevated temperatures on properties of concrete, Fire Safety Journal, 42, 516-522.

ASTM C39/C39M-18. 2018. Standard Test Method for Compressive Strength of Cylindrical Concrete Specimens, ASTM International, PA.

ASTM C78, 2002. Standard Test Method for Flexural Strength of Concrete (Using Simple Beam with ThirdPoint Loading), ASTM International, PA.

ASTM C192, 2002. Standard Practice for Making and Curing Concrete Test Specimens in the Laboratory, ASTM International, PA.

Cioni, P., Croce, P., Salvatore, W., 2001. Assessing fire damage to RC elements, Fire Safety Journal, 36, 181199.

Department of Disaster Management, 2013. Disaster Report, Ministry of Disaster Management \& Relief, Government of the People's Republic of Bangladesh, pp. 60. 
fib, 2007. Fire Design of Concrete Structures - Materials, Structures and Modelling, Fédération Internationale du Béton, Bulletin 38. Lausanne, p. 97.

Georgali, B. and Tsakiridis, P.E., 2005. Microstructure of fire-damaged concrete - A case study. Cement and Concrete Composites, 27, 255-259.

Haddad, R.H., Al-Saleh, R.J., Al-Akhras, N.M., 2008. Effect of elevated temperature on bond between reinforced concrete, Fire Safety Journal, 43, 334-343.

Hager, I., 2013. Behaviour of cement concrete at high temperature. Bulletin of the Polish Academy of Sciences: Technical Sciences, 61(1), 145-154.

Hertz, K.D., 2005. Concrete strength for fire safety design, Magazine of Concrete Research, 57(8), 445-453.

Hertz, K.D., Sorensen, L.S., 2005. Test method for spalling of fire exposed concrete, Fire Safety Journal, 40, 466-476.

Ichikawa, Y., England, G.L., 2004. Prediction of moisture migration and pore pressure build-up in concrete at high temperatures. Nuclear Engineering and Design, 228, 245-259.

Kalifa, P., Menneteau, D.F., Quenard, D., 2000. Spalling and pore pressure in HPC at high temperatures, Cement and Concrete Research, 30, 1915-1927.

Khalaf, J., 2017. Development of non-linear bond stress-slip models for reinforced concrete structures in fire, PhD thesis, Brunel University, London.

Khoury, G.A., Majorana, C.E., Pesavento, F., Schrefler, B.A., 2002. Modelling of heated concrete, Magazine of Concrete Research, 54(2), 77-101.

Lublóy, E. and György, B.L., 2014. Temperature effects on bond between concrete and reinforcing steel, Journal of Faculty of Civil Engineering, 26, 27-35, DOI:10.14415/zbornikGFS26.03.

Xiao, J. and Konig, G., 2004. Study on concrete at high temperature in China - an overview, Fire Safety Journal, 39, 89-103.

(C) 2021 the Authors. Journal of Engineering Science published by Faculty of Civil Engineering, Khulna University of Engineering \& Technology. This is an open access article under the terms of the Creative Commons AttributionNonCommercial-NoDerivatives License, which permits use and distribution in any medium, provided the original work is properly cited, the use is non-commercial and no Modifications or adaptations are made. 